\title{
Saving Behavior of Women Entrepreneurs in Addis Ababa, Ethiopia
}

\author{
Meshesha Zewdie (MSC) ${ }^{1} \quad$ Dessalegn Shamebo (Ph.D.) ${ }^{2}$ \\ 1.Lecturer at Ethiopian Civil Service University Department of Development Economics and Management \\ 2.Assistant Professor at Ethiopian Civil Service University Department of Development Economics and \\ Management
}

\begin{abstract}
This study tried to analyze determinants of saving behavior and the decision to save of women entrepreneurs engaged in micro and small enterprises (MSE) in Addis Ababa. Descriptive statistics and the Tobit model were used to analyze data collected from 500 respondents working in 6 Woredas of Addis Ababa. The findings of the descriptive analysis showed that the mean annual savings were found to be 7894.32 birr out of the mean annual income of 32461.9 birr for the year 2019. Average propensity to save is 0.24 birr. Moreover, lack of market for products or services, lack of sufficient working capital, and inappropriate working place are the main challenges of saving which faced women entrepreneurs. From the Tobit model econometrics, the number of workers, annual income, enterprise types, and access to credit, access to market, and age of business, are statistically significant determinants of the amount of saving and the decision to save. The marginal effects after the Tobit result also indicate that the predicted value of the dependent variable (amount of saving) among savers is about 9140.61birr and the likelihood of women to save is about $65.5 \%$. Therefore, the findings of the study imply that strong and consistent support from the government, widening alternative sources of finance, improve working areas, training, and building a market network with consumers and producers will play an important role to enhance saving behavior and the decision to save of women entrepreneurs in Addis Ababa
\end{abstract}

Keywords: Women entrepreneur, saving, Tobit model, saving determinant, Addis Ababa

DOI: $10.7176 / \mathrm{JESD} / 12-20-01$

Publication date:October $31^{\text {st }} 2021$

\section{Introduction}

Promoting saving has been the concern of the Government of Ethiopia for several years especially in Growth and Transformation Plan 1 and 2 (GTP1 and GTP2). This is because mass mobilization of savings is essential for the maximization of individual and societal welfare and is an important element for enhancing the economic growth of developing countries in particular.

At the macroeconomic level, since saving contributes to capital formation and investment, it helps countries to predict their future growth (Nga, 2007; Nwachukwu \& Odigie, 2009). At the micro-level, savings can smooth consumption of households, source of finance for human capital formation. More than all, saving is the main source of credit for micro and small enterprises. This is because Micro and Small Enterprises (MSE) are important economic sectors for reducing unemployment and fostering economic growth at the national and regional levels. Their importance and significance are because micro and small businesses are the fundamental basis for building a competitive and all-rounded business environment, as well as they are the basis for transforming agricultural development-led strategies into industrial development strategies.

Mostly, lack of adequate capital to finance newly established enterprises and expanding existing business is a persistent problem facing developing countries in general and Ethiopia in particular. Because of this, developing countries find it difficult to finance investments and micro and small enterprises which is an engine for economic growth through import substitution and export promotion. Hence, poor countries finance their investment and micro and small scale enterprises in the short run partly through internal borrowings, foreign loans, and grants but this would end up with an increased accumulation of national debt and would not be a solution in the long run (Deaton, 2005 \& Rogg, 2006). Consequently, mobilizing saving and identifying determinants of saving behavior of societies in general and women, in particular, is a work not to be left for tomorrow.

In line with this, the persistent increase in inflation about $7.10 \%$ in the year 2014 and $13.6 \%$ in the year 2017 in Ethiopia(World Bank, 2021), also puts significant pressure on the real consumption and savings of individuals, and because of inflation, women entrepreneurs may save more and spend more and has become a conflicting factor in the economy. The core issue here is: Do women entrepreneurs save more or spend more as their income increases or the reverse?

Researchers on the subject of saving tried to identify factors that affect saving( Girma et al.,2013 and Tsega \&Yemane 2014) showed household head education level, livestock holdings, access to credit service, income, investment, training participation, extension contacts, forms of savings and saving motives were found to have a significant influence on the amount of households savings. Moreover, Kulikov et al.,(2007) analyzed saving rates depend more on the transitory income than regular income. Moreover, labor market status or the non-financial 
assets ownership (real estate) and credit access have no significant effect on the household saving behavior, instead, the possession of the durable goods (in particular cars) harms the saving rate.

Even though some studies have been done so far on the saving behavior of households or firms in Ethiopia, many of them focused on households not engaged in formal business-like MSE and not specific to women entrepreneurs. And some researchers used macro-level data but the behavior of economic units on the macro level might not necessarily be the same as on an individual or household level, but dealing with micro-level analysis is important for policymakers to identify determinants of saving behavior at the household or firm-level as the majority of savings has been originated from households and firms. The other motives to conduct this research is most studies done before focused on identifying challenges to the growth of women-owned entrepreneurs and considered saving as one challenge but a limited emphasis on what determines savings of women entrepreneurs (Jemal,2013; Rahel\& Issac, 2011).

According to Jemal (2013), women have many responsibilities in society compared to men, and businesses owned by women are challenged by many economic and social factors compared to men entrepreneurs. Hence better understanding and giving more emphasis to women saving behavior is crucial for the development of business.

\section{Objectives of the Study}

The general objective of the study was to analyze determinants of saving behavior and the decision to save of women entrepreneurs engaged in micro and small enterprises in Addis Ababa.

The specific objectives of the study are:

1. To identify determinants of saving behavior of women entrepreneurs in Addis Ababa.

2. To assess factors affecting a household's decisions to participate in saving.

3. To assess the motives of saving to women MSE owners.

4. To assess the challenges of saving to women MSE owners.

\section{Literature Review}

\subsection{Definition and Concepts of Saving}

Savings is the amount of money left and not consumed or transferred for future consumption after payments of direct taxes are deducted from current income (Cronje, 2009). Smith (1991), define savings numerically as: savings equals income minus consumption (Savings $=$ Income - Consumption). This Implies that savings is the amount of money left from one's earnings after all expenses are deducted.

Saving differs from savings. Saving refers to the avoidance of excess expenditure or reduction in expenditure or cost to increase one's assets, whereas savings refers to an amount of money saved or deposits in savings accounts (https://www.thefreedictionary.com/savings). Thus, saving is a flow variable occurring over time, but savings is a stock variable that exists at any one time.

Regarding types of savers, Whyley \& Kempson( 2000b), identified four types of savers. The first is rainy day savers called dedicated savers to refer to people who save actively and often regularly and with no specific purpose in mind and tend to build up the largest sums. The second is instrumental savers characterized by a pattern of 'save to spend, whereby money is saved for a particular purpose and then spent. For instrumental savers, the main motive of saving money is spending and many find it difficult to save without a particular goal in mind. The third and fourth types of savers are passive savers and non-savers respectively.

\subsection{Theoretical Literature}

The saving behavior of economic agents can be explained by the following theories: Absolute Income Hypothesis by Keynes (1936), Life-Cycle Hypothesis by Modigliani (1963), Permanent Income Hypothesis by Friedman (1957), and Relative Income Hypothesis by Duesenberry (1949).

\section{The Absolute Income Hypothesis (J. Keynes 1936)}

The Absolute Income Hypothesis ( $\mathrm{AIH})$ which is developed by Keynes explained that consumption and saving are an increasing function of disposable income. Consumption will increase as disposable income increases. The consumption function as a function of disposable income can be written as a linear function of:

$\mathrm{C}=\mathrm{f}\left(\mathrm{Y}^{\mathrm{d}}\right)$

$\mathrm{C}_{\mathrm{t}}=\alpha_{0}+\alpha_{1} \mathrm{Y}_{\mathrm{t}}^{\mathrm{d}}$

Where: $\mathrm{C}$ is consumption, $\mathrm{Y}_{\mathrm{d}}$ is disposable income.

$\mathrm{C}_{\mathrm{t}}$ the total consumption at time $\mathrm{t}, \alpha_{0}$ autonomous consumption, which represents consumption without income. $\alpha_{1}$ is the marginal propensity to consume (MPC), $\mathrm{Y}_{\mathrm{t}}^{\mathrm{d}}$ is disposable income at time $\mathrm{t}$. The Keynesian saving function takes a form of a linear function with the constant marginal propensity to save (MPS):

$\mathrm{S}_{\mathrm{t}}=\mathrm{c}+\beta \mathrm{Y}_{\mathrm{t}}$

Where: $\mathrm{S}_{\mathrm{t}}$ is saving, $\mathrm{Y}_{\mathrm{t}}$ is disposable income, $\mathrm{c}$ is constant and $\mathrm{c}<0$ implying that at low levels of income savings will be negative, and $\beta$ is the marginal propensity to save and $\beta: 0<\beta<1$. Therefore, Keynes indicates that absolute 
disposable income is an important determinant of savings.

The life-Cycle Hypothesis (Ando, A., \& Modigliani, F.,1963)

This hypothesis starts with the observation that consumption needs and income are not often equal at various points in the life cycle. The consumption needs of young people mostly exceed their income. Youth needs to be focused mainly on housing and education, and therefore they have little savings. In middle age, earnings generally rise, enabling debts accumulated earlier in life to be paid off and resulted in incomes to decline in the retirement age and individuals consume out of previously accumulated savings during retirement.

Therefore, as the age of the population increases and the relative proportion of the population of those reaching retirement age grow relative to the middle-aged population, the life-cycle hypothesis predicts a reduction in aggregate savings.

\section{Permanent Income Hypothesis (Friedman, M. (1957)}

Milton Friedman, (1957) proposed the permanent-income hypothesis to explain consumer behavior. Friedman's permanent income hypothesis complements Modigliani's life-cycle hypothesis: both use Irving Fisher's theory of the consumer to argue that consumers should not depend on current income alone but people experience random and temporary changes in their incomes from year to year, different from the life-cycle hypothesis, which emphasizes that income follows a regular pattern over a person's lifetime.

Friedman suggested that we need to categorize current income $\mathrm{Y}$, into permanent income $\mathrm{Y}^{\mathrm{P}}$ and transitory income $\mathrm{Y}^{\mathrm{T}}$. That is, $\mathrm{Y}=\mathrm{Y}^{\mathrm{P}}+\mathrm{Y}^{\mathrm{T}}$. Permanent income is the part of income that people expect to remain into the future and Friedman argues that consumption should depend primarily on permanent income because consumers use saving and borrowing to smooth consumption in response to transitory changes in income. On the other, hand transitory income is the part of income that people do not expect to continue. In another way, permanent income is average income, and transitory income is the random deviation from that average income.

Furthermore, Permanent-Income Hypothesis explains about average propensity to consume which depends on the ratio of permanent income to current income. When current income temporarily increases above permanent income, the average propensity to consume temporarily falls; when current income temporarily falls below permanent income, the average propensity to consume temporarily rises.

\section{Relative income Hypothesis (Duesenberry, 1949)}

Duesenberry (1949) hypothesized that household consumption function depends on household income about other household income, as a result, for any given relative income distribution, the percent of income saved by a household will tend to be unique, invariant, and increasing function of its percentile position in the income distribution. The hypothesis assumes that the percent of income saved and the aggregate saving ratio will be independent of the absolute level of income. This is because, Duesenberry assumed that consumption is irreversible over time, as income decrease consumption will not fall at the same rate as households imitate consumption of their neighbors.

\subsection{Factors influencing saving}

The main policy variables that affect the saving behavior of individuals are financial market development, revenue policy (tax structure, tax incentive), expenditure policy (transfers, income redistribution), social security arrangement, government savings, and macroeconomic dependability. The non-policy factors to influence savings behavior are economic development, demographics, and external elements. These elements themselves may be impacted by financial strategy and are not policy variables (Akpokodje, 2004).

Micro-level researches on household savings identified the following factors: household head education level, livestock holdings, access to credit service, income, investment, training participation, contact with extension workers, saving motives, cultural background, social affairs, planning and expenditure controlling habit, age, marital status, sex, the form of institutions used for saving, and frequency of getting money are main factors in affecting household saving (Tsega \& Yemane, 2014; Girma et al., 2013).

ILO (2004) also differentiated the following factors affecting women entrepreneurs not to save more and expand their business. These are family responsibilities, political instability, poor infrastructure, high costs of production, weak access to market information, gender biases, limited access to rapid technological change and finances, lack of training, low level of education, and an altogether unfavorable business environment are among the major determinants of saving behavior of women.

\section{Data and Methods}

\subsection{Study Design}

The study was used the explanatory survey method because the main purpose of the study is to identify determinants of saving behavior of women entrepreneurs and both quantitative and qualitative cross-sectional data was collected from samples drawn from women-owned micro and small enterprises. 


\subsection{Types and Source of Data}

The primary data related to the saving behavior of women entrepreneurs who are officially engaged in micro and small enterprises was used as a source of data. The population of the study from which a sample was drawn was all women entrepreneurs formally established by the government body, licensed and actively working either in a sole proprietorship, partnership, or cooperative in the found in the selected sub-cities of Addis Ababa.

\subsection{Sample size determination and sampling techniques}

The population from which the sample will be drawn is finite, the formula provided by Kothari, 2004 will be applied to determine the sample size of 500. That is:-

$\mathrm{n}=\frac{z^{2} \cdot p \cdot q \cdot N}{e^{2}(N-1)+z^{2} \cdot p \cdot q}$

Where; $\mathrm{N}=$ size of the population, $\mathrm{n}=$ size of sample $\mathrm{e}=$ acceptable error (the precision),

$\mathrm{p}=$ proportion of the population with major interest estimated either based on Personal judgment from experience or the result of the pilot study. $q=1-p$

$\mathrm{Z}=$ the value of the standard variate at a given confidence level and can be obtained from the table showing area under the normal curve (the common is at $95 \%$ Confidence level that gives $Z$ value 1.96).

Regarding the values of " $\mathrm{e}$ " and " $\mathrm{p}$ ", there is no clear and consistent evidence of ' $\mathrm{e}$ ' and ' $\mathrm{p}$ ' in literature and studies. Different studies assumed ' $\mathrm{e}$ ' value and ' $\mathrm{p}$ ' differently. Therefore to this study, the value of 'e' is assumed as $4 \%$ and the value of ' $p$ ' as $50 \%$ using estimation of the population with major interest and own personal judgment. Thus for $\mathrm{N}=3000, \mathrm{e}=0.04, \mathrm{p}=0.50, \mathrm{q}=0.5$ and $\mathrm{z}=1.96$, the sample size (n) will be:

$$
\mathrm{n}=\frac{z^{2} \cdot p \cdot q \cdot N}{e^{2}(N-1)+z^{2} \cdot p \cdot q}=\frac{3.8416 * 0.05 * 0.5 * 3000}{4.7984+0.96}=500
$$

From the formula provided by Kothari 2004, the sample size was determined to be 500. By two-stage random sampling techniques, first, 3 sub-cities named: Addis Ketema and Arada and Kolfie were chosen among 10 subcities found in Addis Ababa city administration (lottery system). And from these three (3) sub-cities understudy, two (2) Woreda from each sub-city (Addis Ketema sub-city has 10 Woreda, Arada sub-city has 10 Woreda and Kolfie sub-city has 15 Woreda), a total of six (6) Woredas were selected by simple random sampling technique. Depending on the number of women-owned enterprises in the selected Woredas and probability sampling proportional to size, samples to be drawn were determined in each Woreda. Then, business sectors, in which women engaged, were stratified into trade (service), manufacturing and construction sectors. Lastly, by systematic random sampling, samples were drawn from each stratum, that is, trade (Service), manufacturing, and construction sector from each Woreda. Similarly, the study made 1(one) focus group discussion (FGD) consisting of ten (10) members who are more familiar with the MSE works. Primary data was collected by using a structured questionnaire and focus group discussion. To analyze the collected data, both descriptive and econometrics data analysis methods were used

\subsection{Econometrics model specification}

Tobit Model (Tobin 1958) was used to analyze major determinants of saving behavior and decision to participate of women entrepreneurs. This model is chosen because the amount of household savings tend to be censored at the lower limit of zero (Gujarati, 2007).

The Tobit model specification is given as ((Tobin, 1958; Cameron and Trivedi, 2009; Greene, 2012):

$\mathrm{Y}_{\mathrm{i}}=X_{i} \beta+\varepsilon_{i} \quad i=1,2, \ldots \ldots \ldots$

$\mathrm{Y}_{\mathrm{i}}= \begin{cases}\mathrm{yi}=\mathrm{Xi} \beta+\varepsilon \mathrm{i} & \text { if yi } *>0 \\ 0 & \text { if yi } * \leq 0\end{cases}$

$\varepsilon_{\mathrm{i}} \sim$ i.i.d. $\mathrm{N}\left(0, \sigma^{2}\right)$

Where:

$\mathrm{Y}_{\mathrm{i}}$ : the observed amount of household savings

$\mathrm{Y}_{\mathrm{i}}^{*}$ is the latent variable that is not observed

$\beta$ is Vector of unknown parameters

$\mathrm{X}_{\mathrm{i}}$ is the vector of independent variable affecting household savings. These are the age of respondent, age of the business, number of workers, family size, education level, working premises, annual income, annual expenditure, credit availability, training, access to market, and enterprise type.

The threshold value in the above model is zero. The model parameters are estimated by maximizing the Tobit likelihood function of the following form (Maddala, 2005; Gujarati, 2007).

$\mathrm{L}=\Pi_{\mathrm{Yi}^{*}} \frac{1}{\sigma} f\left\{\frac{Y i-\beta \mathrm{iXi}}{\sigma}\right\} \Pi_{\mathrm{Yi}^{*} \leq 0} \mathrm{~F}\left\{\frac{\beta \mathrm{iXi}}{\sigma}\right\}$

Where $f$ and $\mathrm{F}$ are the density probability function and cumulative distribution function of $\mathrm{Y}_{\mathrm{i}}{ }^{*}$ respectively. $\pi$ means the product over I for which $\mathrm{Yi}^{*} \leq 0$, and $\pi \mathrm{yi}^{*}>0$ means the product over those I for which $\mathrm{Yi}^{*}>0$. Decomposition techniques were used to analyze the effects of explanatory variables on the probability of 
respondent savings.

1. The change in the probability of saving participation as independent variable $\mathrm{X}_{\mathrm{i}}$ changes are:

$\frac{\partial \mathrm{F}(\mathrm{Z})}{\partial \mathrm{Xi}}=(\mathrm{z}) \frac{\beta \mathrm{i}}{\sigma}$

2. The change in intensity (amount) of saving with respect to a change in an explanatory variable among the savers' category:

$\partial \mathrm{E}\left(Y i / Y i^{*}>0\right) / \partial X i=\beta i\left[1-Z(z) / F(z)-(f(z) / F(z))^{2}\right]$

$\mathrm{F}(\mathrm{z})$ is a cumulative normal distribution of $\mathrm{z}, \mathrm{f}(\mathrm{z})$ is the value of the derivative of the normal curve at a given point (i.e. unit normal density), $\mathrm{Z}$ is the zero score for the area under the normal curve, $\beta$ is a vector of Tobit maximum likelihood estimate and $\sigma$ is the standard deviation of the error term.

\subsection{Definition of Variables}

Dependent and independent variables used in this study were defined and summarized (Table 3.1) under the following sub-topics.

\section{Dependent Variables}

The dependent variable is the amount of saved money by respondents in birr and it is a continuous variable.

Independent Variables and their Definition

Age of respondents (Age R): It is a continuous variable and hypothesized to affect the saving amount and the decision to save either positively or negatively.

Age of the Business (Age B): It is a continuous variable and hypothesized to affect the saving amount and the decision to save either positively or negatively. It was used as a proxy for experience in managing the business.

The number of employees (emply): This is a continuous variable and hypothesized to affect savings and the decision to save either positively and negatively.

Education level (Educ): It is a categorical variable that assumes a value of "1-6" for different categories of education of respondents. It was hypothesized either negatively or positively in affecting savings and decisions to save.

Enterprise type (Enterp type). Women enterprise types can be micro and small. It is a dummy variable that assumes 1 if the business is small and " 0 " otherwise. It is hypothesized that small business saves more than micro. Credit availability (Crdt): It is a dummy variable that assumes " 1 " if the respondent gets credit and " 0 " otherwise. It indicates whether the respondents get credit from friends, relatives, private microfinance, government, and nongovernmental organization. It is hypothesized positively in affecting savings and the decision to save.

Training (Train): This is a dummy variable that assumes a value " 1 " if the respondent gets training on how to save "0" otherwise. It is hypothesized positively in affecting savings and the decision to save.

Family Size (famsize): It is a discrete variable and hypothesized to affect saving amount positively or negatively. Access to market (mrkt): This is a dummy variable that assumes a value "1" if respondent faced no market problem " 0 " otherwise. It is hypothesized positively in affecting savings.

Annual income (Income): It is a continuous variable and hypothesized to affect saving amount positively.

Annual expenditure (Expend): It is a continuous variable and hypothesized to affect saving amount negatively.

Working premises (work_prm): It is a dummy variable and hypothesized to affect saving positively

Table 3.1: Summary of dependent and independent variables

\begin{tabular}{|l|l|l|c|}
\hline Variables Code & Description & Types of variable & Hypothesized sign \\
\hline I . Dependent variable & & & \\
\hline Y(Annual savings of 2019) & Amount of saved money & Continuous & 0 \\
\hline II. Independent Variables & & & \\
\hline Age R & Age of respondents & Continuous & $+/$ \\
\hline Age B & Age of the Business & Continuous & $+/$ \\
\hline Emply & Number of employees & Continuous & $+/$ \\
\hline Educ & Education level of respondents & Dummy & $+/$ \\
\hline Work_prm & Working premises & Categorical & + \\
\hline Crdt & Credit availability & Continuous & + \\
\hline Train & Training & Dummy & + \\
\hline famsize & Family Size & Discrete & $+/$ \\
\hline Enterp_type & Enterprise type & Categorical & $+/-$ \\
\hline mrkt & Access to market & Dummy & $+/$ \\
\hline Income & Annual income & Continuous & + \\
\hline Expend & Annual expenditure & Continuous & - \\
\hline
\end{tabular}




\section{Results and Discussions}

\subsection{Enterprise Involvement of Women}

The survey result indicated that $76.2 \%$ of respondents were engaged in small enterprises and the remaining $23.8 \%$ were involved in the micro-enterprise. Women entrepreneurs involved in this study were those who have started to work from 2007 to 2019 and their business is on average 3.26 years old with a standard deviation of 1.9. Similarly, out of the total respondent, 329(65.8\%) save some part of their income while 171(34.2\%) did not participate in saving. A convenient working premise is one of the important requirements for enterprisers to have a market advantage. Accordingly, $97.2 \%$ of respondents replied that they have working premises and the remaining $2.8 \%$ said they do not have working premises and $67 \%$ of them used government shades. Regarding the number of employees permanent or temporary, business owners have on average 1.5 employees with minimum and maximum 0 and 9 respectively (Table 5.1).

Appropriate and sustainable source of finance is an essential factor in determining the growth of the business. Consequently, the descriptive result showed that $60 \%$ of respondents said they used their source to finance their business. This implies getting finance from other sources is very challenging. Respondents were also asked about the type of business they are working with and replied $64.8 \%$ of them were engaged in trade or service. Even though the highest percentage of women were engaged in the trade or service sector, the mean annual saving is highest for women engaged in the manufacturing sector(11600 birr per year) and second-highest for the trade sector(6397.40 birr per year) and the last is construction(1875 birr per year). The qualitative response from FGD also supports this finding. The discussant of FGD pointed out that they gave more support for those entrepreneurs engaged in manufacturing as this sector is the core sector in the Ethiopian economy to realize the transformation of the agricultural sector to industry and it is one of the key strategic directions of the MSE sector.

Table 5.1.Descriptive results of Variables

\begin{tabular}{llll}
\hline Variables & Response & Frequency & Percent \\
\hline Work premises & yes & 486 & 97.2 \\
Ownership of & Wo & 14 & 2.8 \\
premises & No working premises & 14 & 2.80 \\
& Own premise & 116 & 23.20 \\
\multirow{2}{*}{ Source of Finance } & Government shade & 335 & 67.00 \\
& Rented & 35 & 7.00 \\
\multirow{2}{*}{ Types of Business } & Own & 300 & 60.00 \\
& Credit & 62 & 12.40 \\
& Own and credit & 138 & 27.60 \\
& Trade/service & 324 & 64.80 \\
& Manufacturing & 159 & 31.80 \\
\hline
\end{tabular}

Source: Own computation, 2021

\subsection{Income, Expenditure and Saving Patterns of Respondents}

Respondents were asked to reply with their monthly gross income, expenditure, and saving a month preceding this survey and as well as yearly gross income, consumption expenditure, and savings. As a result, the average monthly income, expenditure, and savings of respondents which is computed a month preceding this survey (December, 2019) were found to be $3370.36,2505.56$, and 895.26 birr sequentially. And annual income, expenditure, and savings of respondents were 32461.9, 24603.58, and 7894.32 birr respectively for the year 2019.

The t-test result indicates that the mean difference between annual income and annual saving is statistically significantly different from zero $(\mathrm{t}=-25.88, \mathrm{p}=0.000)$. In line with this, the result showed that only $329(65.8 \%)$ of respondents saved some part of their income and the remaining 171(34.2\%) did not save any portion of their income they obtained from micro or small enterprises business operations (Table 5.2). From the collected data, the average propensity to save which is the ratio of total savings to total income is found to be 0.24 birr (Average propensity to save $($ Aps $)=500 * 7894.32 / 500 * 32461.9)$.

Table 5.2 Mean monthly and yearly income, expenditure, and savings for the year 2019.

\begin{tabular}{llllll}
\hline Variable & Obs & Mean & Std.dev & Min & Max \\
\hline Monthly Income & 500 & 3370.36 & 3210.412 & 100 & 36000 \\
Monthly Expenditure & 500 & 2505.56 & 2398.457 & 100 & 29500 \\
Monthly Savings & 500 & 895.26 & 1284.362 & 0 & 11500 \\
Annual Income & 500 & 32461.9 & 29690.3 & 2000 & 234000 \\
Annual Expenditure & 500 & 24603.58 & 21277.32 & 2000 & 180000 \\
Annual Savings & 500 & 7894.32 & 11839.24 & 0 & 72000 \\
\hline
\end{tabular}

Source: Own computation, 2021 


\subsection{Motives and Challenges of Savings}

Savers were asked to express their motives behind saving and gave several reasons as to why they are motivated to save. As a result, 313(95.1\%), 260(79\%), 222(67.5\%), and 207(62.9\%) of respondents were motivated to save to expand /undertake new business, to buy things necessary for life, to meet unexpected expenses and to pay for education respectively. Others were motivated to pay for condominiums, to have more money in their account, and save for retirement (Figure 5.1).

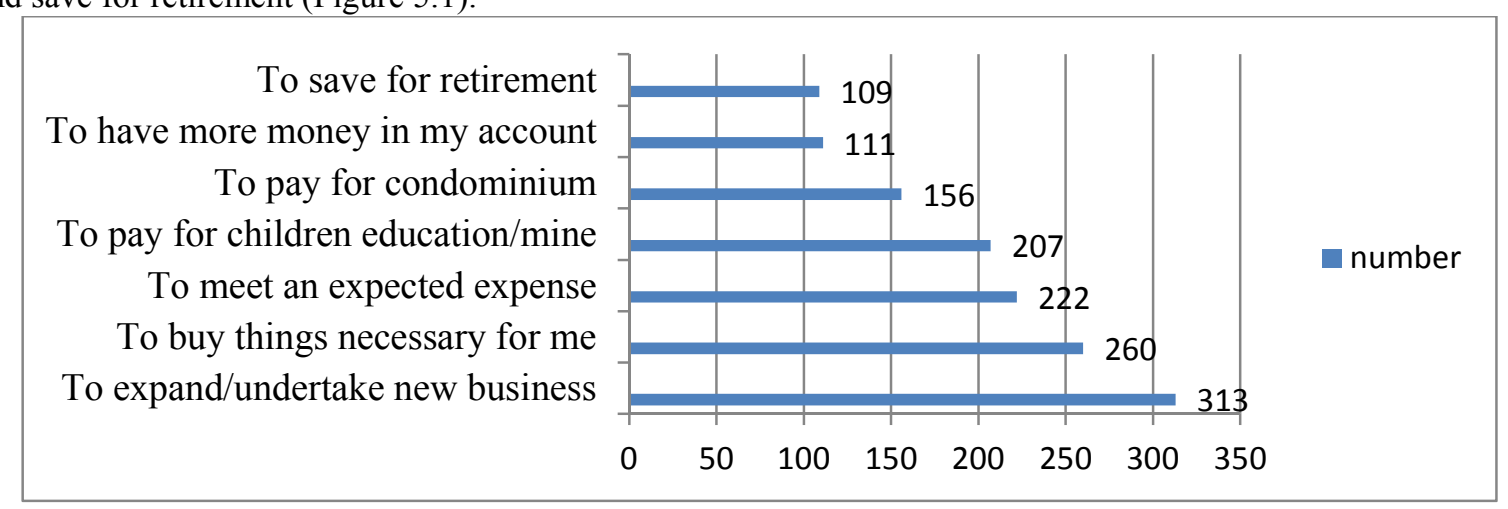

Figure 5.1. Motives for Saving

In low-income societies, saving is not a simple activity. It is impacted by economic, social, and cultural factors. To this end, non-savers were asked to reason out challenges of not- saving. Accordingly, the findings of the survey revealed that lack of market, lack of sufficient working capital, inappropriate working place, poor support from MSE office, and lack of training are the main challenges of not to save which constitute $89.9 \%, 89.4 \%, 58.9 \%$, $52.7 \%$ and 51.2\% respectively(Table 5.3). This finding implies that lack of market for products or services of women entrepreneurs, lack of sufficient working capital, and inappropriate working place are potential challenges that need attention by the government. Therefore, to promote women entrepreneurs and enhance their saving all concerned offices should emphasize solving the problem of the market and facilitate sufficient working capital.

Table 5.3Challenges for not saving

\begin{tabular}{llll}
\hline Challenges to Non-Savers & Response & Frequency & Percent \\
\hline \multirow{2}{*}{ Lack sufficient working capital } & yes & 152 & 89.4 \\
Inappropriate working place & no & 18 & 10.6 \\
& yes & 99 & 58.9 \\
Lack of training & no & 69 & 41.1 \\
Lack of Market & nes & 85 & 51.2 \\
& yes & 81 & 48.8 \\
Weak attitude towards women-owned business & no & 151 & 89.9 \\
& yes & 17 & 10.1 \\
Lack of experience to manage my business & no & 30 & 18.1 \\
Poor support from MSE Office & yes & 136 & 81.9 \\
& no & 72 & 43.4 \\
\hline
\end{tabular}

Source: Own computation, 2021

\subsection{Econometric Results}

\subsubsection{Determinants of saving amount and decision to save}

The result of the Tobit model in identifying determinants of savings is presented in terms of marginal effect (Table 5.4) because it is meaningless to interpret the coefficients of the Tobit result as it is. So that marginal effects of changes in the probability of participation and the change in intensity (amount) of saving with respect to a change in an explanatory variable among the savers' category were computed after Tobit regression.

The Tobit log-likelihood ratio, LR ch2, is statistically significant at a $1 \%$ statistical level. This implies variables entered in the model jointly explained the dependent variable. Similarly, the Tobit model result suggests that out of 10 explanatory variables six (6) variables were found to be statistically significant in explaining households' decision to save and amount of saving. The econometrics analysis result showed that annual income 2019 , access to credit, number of employees, access to market, age of business, and enterprise types had a significant relationship with the decision to save and amount of saving. The marginal effects after the Tobit result indicate that the predicted value of the dependent variable (amount of saving) among savers is about 9140.61birr 
and the likelihood of women to save is about $65.5 \%$ ( Table 5.4).

The descriptive analysis showed that women entrepreneurs have, on average 1.5 employees with a maximum of workers 9. One of the objectives of micro and small businesses is the creation of job opportunities for workers. However, if MSE employees are more than the limit their variable cost increases, and savings will decrease. Therefore, the econometrics result depicted that if the women entrepreneurs employ one more worker their amount of saving and decision to save will fall by 527.52 birr and $4.4 \%$ sequentially and statistically significant at $1 \%$ level (Table 5.4).

The annual income of 2019 is one important variable that affects savings amount and decision to save. A one percent increase in annual income is associated with a 62 birr increase in annual savings amount and whereas the decision to save changes by $52.5 \%$ and is significant at $1 \%$ level (Table 5.4 ).

Access to credit is another variable that affects women entrepreneur savings. As shown in table 4.7 women entrepreneurs who had no access to credit saved lower by about 3648.04 birr compared to those who had access to credit and the difference is statistically significant at a $1 \%$ level. At the same time the decision to save for those women entrepreneurs who had no access to credit lowered by $30.7 \%$ compared to those who had access to credit. On the other hand, a year increase in age of a business increases saving amount and decision to save by about 299.33 birr and $2.5 \%$ respectively and statistically significant at $5 \%$ level ( Table 5.4 ).

The market is one of the most important factors that determine the amount of savings. The econometrics result showed that for women entrepreneurs who had no access to the market their decision to save and saving amount decreased by about $20 \%$ and 2381.59 birr respectively compared to those who had access to the market and the difference is statistically significant at $1 \%$ level.

Enterprise type is another variable that affects the saving amount and the decision to save at a $1 \%$ level of statistical error. Compared to micro enterprises, small enterprises increase the amount of saving and the decision to save by about 2429.67 birr and $20.5 \%$ respectively. This may be because the size of a small enterprise is bigger than a micro and small enterprise plays an important role in the business environment. This result is in line with the findings of Kipesha (2013) who confirm the positive contribution of firm size for a business operation to get the market advantage.

Table 5.4: Tobit model Estimation result

\begin{tabular}{|c|c|c|c|c|}
\hline Age of Respondents & 98.58 & 79.43 & 45.27 & 0.004 \\
\hline Work premises & -7553.93 & 4659.51 & -3469.13 & -0.29 \\
\hline Family size & -87.98 & 346.17 & -40.41 & -0.003 \\
\hline Number of employees & $-1148.67 * * *$ & 347.33 & $-527.52 * * *$ & $-0.044 * * *$ \\
\hline Annual income 2019(ln) & $6208.184^{* * *}$ & 753.41 & $0.23 * * *$ & $0.525 * * *$ \\
\hline Access to credit & $-7943.51 * * *$ & 1238.73 & $-3648.04 * * *$ & $-0.307 * * *$ \\
\hline Training & -1785.63 & 1189.58 & -820.05 & -0.069 \\
\hline Market & $5185.84 * * *$ & 1147.02 & $2381.59 * * *$ & $0.20^{* * *}$ \\
\hline Age of business & $651.79 * *$ & 305.32 & $299.33 * *$ & $0.025 * *$ \\
\hline Enterprise type & $5290.53 * * *$ & 1363.91 & $2429.67 * * *$ & $0.205^{* * *}$ \\
\hline Const & -128489.8 & 11507.71 & & \\
\hline Sigma & 9507.79 & 378.56 & & \\
\hline \multirow{2}{*}{$\begin{array}{l}\text { Log-likelihood } \\
\text { LRChi2(10) }\end{array}$} & -3561.90 & & & \\
\hline & $454.91 * * *$ & & & \\
\hline Prob $>$ Chi 2 & 0.000 & & & \\
\hline Pseudo R2 & 0.0600 & & & \\
\hline Number of Obs & 500 & & & \\
\hline Left censored obs & 171 & & & \\
\hline $\begin{array}{l}\text { Uncensored obs } \\
\end{array}$ & 329 & & & \\
\hline \multicolumn{5}{|c|}{$\begin{array}{l}-\quad \mathrm{y}=\operatorname{Pr}(\text { Annual_save2019>0) (predict, pr }(0, .)) \text {, probability of participation }=0.65501917 \\
\text { - } \quad \mathrm{y}=\mathrm{E}(\text { Annual_save2019|Annual_save2019>0) (predict, } \mathrm{e}(0, .)) \text {, for savers }=9140.6129 \\
\text { - The dependent variable: Annual Saving } 2019 \text { in birr. } \\
\text { - The reference category for enterprise-type is micro; the reference category for work premises is "no"; } \\
\text { the reference category for access to training dummy is trained (yes), and the reference category for the } \\
\text { variable access to credit "yes"(got credit); the reference category for the variable access to market }\end{array}$} \\
\hline
\end{tabular}




\section{Conclusion}

Appropriate working premises are one of the important requirements for enterprisers to have a market advantage. As a result, $97.2 \%$ of respondents replied that they have working premises and the remaining $2.8 \%$ said they do not have working premises. But proper working premises are challenges for most women entrepreneurs. The descriptive result also indicates lack of market $(89.9 \%)$, Lack of sufficient working capital $(89.4 \%)$, and inappropriate working place (58.9\%) are the main challenges of not saving.

There are a lot of motives that encourage savers to save more. Among all, to expand business operation $(95.1 \%)$, to buy things essential for life $(79 \%)$, and to meet unexpected expenses $(62.9 \%)$ were potential factors that motivate savers. The descriptive analysis showed that the mean annual savings were found to be $7894.32 \mathrm{birr}$ out of the mean annual income of 32461.9 birr for the year 2019 and the average propensity to save is 0.24 birr.

Tobit model result showed that numbers of workers, annual income, enterprise types and access to credit, access to market, age of business, are statistically significant determinants of the amount of saving and decision to save by women entrepreneurs.

The annual income of 2019 is one important factor that affects savings and the decision to save; a one percent increase in annual income is associated with a 62 birr increase in savings and $52.5 \%$ decision to save and statistically significant at $1 \%$ level. The marginal effects after the Tobit result indicate that the predicted value of the dependent variable (amount of saving) among savers is about 9140.61birr and the likelihood of women to save is about $65.5 \%$.

The government gives the greatest attention to enhance the manufacturing sector of Ethiopia, however, more than $64 \%$ of women entrepreneurs are engaged in trade/service sectors. But, women entrepreneurs engaged in the trade/ service sector save the lower compared to those women entrepreneurs engaged in the manufacturing sector.

The findings of the study revealed that women entrepreneurs need strong and consistent support from the government especially the one related to the market. Because the main problem of the market for products and services of women entrepreneurs is associated with failure to compete with other similar enterprises which constitute $61.7 \%$ and lack of government support $(49.6 \%)$ to promote their saving behavior. Furthermore, encouraging women entrepreneurs to engage in the manufacturing sector, widening alternative sources of finance, improve working areas, promoting micro-enterprises to small enterprises, training, and building market network with consumers and producers will play an important role to enhance saving behavior and the decision to save of women entrepreneur.

\section{References}

Akpokodje, G., Lancon, F., Erenstein, O., and Toure, A. A. (2004).Savings trends and behavior in Nigeriall.West African journal of monetary and economic integration. 2(2), 87 - 102.

American Heritage ${ }^{\circledR}$ Dictionary of the English Language, Fifth Edition. (2011). Retrieved December 202018 from https://www.thefreedictionary.com/savings

Ando, A., and Modigliani,F.(1963). The "life cycle" hypothesis of saving: Aggregate implications and tests. American Economic Review, 53(1), 55-84.

Ayalew, H. (2013). Determinants of Domestic Saving in Ethiopia: An Autoregressive Distributed Lag (ARDL) Bounds Testing Approach. Journal of Economics and International Finance, 5(6): 248-257.

Boateng, I. K. (1994).Basic business knowledge and consumer skills. An Unpublished Masters Thesis, University of Ghana, Ghana.

Cameron, A.C. and T.K. Trivedi (2009). Microeconometrics Using Stata, Stata Corp Ltd, USA

Cantor,R., and Yuengart,A.(1994). "The Baby Boom Generation and Aggregate Savings."Federal Reserve Bank of New York Quarterly Review (Summer/Fall 1994)

Cronje, M. (2009). Creating a Savings Culture for the Black Middle Class in South Africa Policy Guidelines and Lessons from China and India. University of Stellenbosch, South Africa

De Mel, S., McKenzie, D., and Woodru, C. (2008). Returns to capital in microenterprises: evidence from aold experiment. The Quarterly Journal of Economics, 123(4), 1329-1372.

Deaton, A. S. (2005). Franco Modigliani and the Life Cycle Theory of Consumption.Banca Nazionaledel Lavoro Quarterly Review.

Devaney, S.A., S.T. Anong, and S.E. Whirl, (2007).Household Savings Motives. Journal of Consumer Affairs 41(1): 174-186.

Girma, T., Belay, K.; Bezabih, E., and Jema H. (2013). Determinants of Rural Household Savings in Ethiopia: The Case of East Hararghe Zone, Oromia Regional State. Journal of Economics and Sustainable Development, Vol.4, No.3, 2013

Greene, W. H. (2012). Econometric Analysis ( $7^{\text {th }}$ Edition). New Jersey: Pearson Hall, USA

Gujarati, D.N., (2007). Basic Econometrics. Fourth edition.McGraw-hill, Inc., New York.

Henrik, C., and Stephan, S.(2010). The Origins of Savings Behavior Electronic copy available at: http://ssrn.com/abstract $=1649790$ 
Issahaku and Haruna. (2011). Determinants of saving and Investment in Deprived District Capitals in Ghana -A Case Study of Nadowli in the Upper West Region of Ghana", WiloludJournals, Continental J. Social Sciences 4 (1): 1 - 12,

International Labour Organization(ILO). (2004), "Supporting growth-oriented women entrepreneurs in Ethiopia, Kenya and Tanzania", an Overview Report Prepared by International Labour Office (ILO), SEED Programme and African Development Bank (AFDB) Private Sector Department (OPSD), July, p. 7.

Jemal, A(2013). The challenges of Women in micro and small enterprises, Addis Ababa University Department Public Administration and Development Management

Ken, K. (2003).“Maximizing the benefits of globalization for Africa", paper presented at International Conference on Trade and Investment, Dakar, 23-26 April.

Khan, T ; Gill, A.,andHaneef, S. (2013). Determinants of Private Saving: A Case of Pakistan ${ }^{\circledR}$. Asian Journal of Economic Modelling, 1(1):1-7.

Gujarati, D.N., (2007). Basic Econometrics.Fourth edition.McGraw-hill, Inc., New York.

Kothari, C.R. (2004). Research Methodology: Methods and Techniques. $2^{\text {nd }}$ edition. New Age International Publications. Dharmesh Printers, Delhi.

Kulikov, D., A. Paabut and K. Staehr, (2007). A Micro econometric Analysis of Household Saving in Estonia: Income, Wealth and Financial Exposure. Working Paper $n^{\circ} 8$, Estonian National Bank.

Lusardi, A., Schneider, D. J., and Tufano, P. (2011).Financially fragile households: Evidence and implications(NBER Working Paper No 17072). Cambridge, MA: National Bureau of Economic Research.

Maddala, G.S. (2005). Introduction to Econometrics.3rd Edition John Wiley \& Sons (Asia) pte. Ltd, Singapore.

Nga, M.T., (2007). An Investigative Analysis into the Saving Behavior of Poor Households in Developing Countries: With Specific Reference to South Africa. An MSC Thesis Presented to the Department of Economics, University of the Western Cape. South Africa.

Nwachukwu, T. and P. Odigie, (2009). What Drives Private Saving in Nigeria. Centre for the Study of African Economies Conference, University of Oxford.

Rogg, C. (2006). Asset Portfolios in Africa Evidence from Rural Ethiopia. UNU-WIDER, Centre for the Study of African Economies, University of Oxford. Department for International Development (UK).Research Paper No. 2006/145.

Tobin, J. (1958). Estimation of relationships for limited dependent variables. Econometrica, 26: 24-36

Tsega, H., and Yemane, M., (2014). Determinants of household saving in Ethiopia- the case of North Gondar Zone, Amhara Regional State International Journal of Development and Economic SustainabilityVol.2, No.4, pp.37-47, October 2014Published by European Centre for Research Training and Development UK (www.eajournals.org)

Whyley, C., and Kempson, E. (2000b). Understanding small savers. Peterborough: AMP.

World Bank. (2020). https://www.macrotrends.net/countries/ETH/ethiopia/inflation-rate- cpi'>Ethiopia Inflation Rate

Yuh, Y., and Hanna, S. D. (2010). Which households think they save? The Journal of Consumer Affairs, 44(1), 70-97.

Zhu, Q. (2004). The Impact of Rural Enterprises on Household Savings in China. ZEF - Discussion Papers on Development Policy Bonn, Germany. 